\title{
A New Inhibitor Approach to the Corrosion of Mild Steel in Acidic Solution with Long-Term Impedance Tests: A New Application Area for Hypnum cupressiforme (Bryophyta)
}

\author{
Demet ÖZKIR $^{1 * i D}$, Tülay EZER ${ }^{2,3}$ \\ ${ }^{I}$ Niğde Ömer Halisdemir University, Faculty of Arts \& Sciences, Department of Chemistry, Niğde \\ TURKEY \\ ${ }^{2}$ Niğde Ömer Halisdemir University, Faculty of Arts \& Sciences, Department of Biology, Niğde, TURKEY \\ ${ }^{3}$ Niğde Ömer Halisdemir University, Faculty of Architecture, Department of Landscape Architecture,
} Niğde, TURKEY

\begin{tabular}{lll}
\hline Received: 10 July 2020 & Revised: 30 September 2020 & Accepted: 09 October 2020 \\
\hline
\end{tabular}

\begin{abstract}
The most important aspect of this study is that the effect of Hypnum cupressiforme Hedw. which is a bryophyte species as a "green inhibitor" on the corrosion behavior of mild steel in $1.0 \mathrm{M} \mathrm{HCl}$ solution at $298 \mathrm{~K}$ is being examined for the first time. The inhibitory effect of moss extract was investigated applying the electrochemical impedance spectroscopy (EIS) technique. Nyquist diagrams were performed by EIS to examine the variation of the different concentrations of the extract with some immersion-time parameters. Also, the surface charge of the metal in terms of the inhibition mechanism was determined by the EIS technique and as a result, it was found that the protonated inhibitor molecules were adsorbed directly onto the metal surface. The surface morphology studies of working electrodes were performed using field emission scanning electron microscope (FESEM) and optical metal microscopy techniques. Electrochemical tests and surface analysis studies support each other.
\end{abstract}

Keywords: Bryophyte, Hypnum cupressiforme, Green inhibitor, Acidic corrosion, EIS.

\section{Uzun Süreli İmpedans Testleri ile Asidik Çözeltideki Yumuşak Çeliğin Korozyonuna Yeni Bir İnhibitör Yaklaşımı: Hypnum cupressiforme (Bryophyta) için Yeni Bir Uygulama Alanı}

$\ddot{O} z$

Bu çalışmanın en önemli yönü, $298 \mathrm{~K}$ 'de 1,0 M HCl çözeltisindeki yumuşak çeliğin korozyon davranışına, bir briyofit türü olan Hypnum cupressiforme Hedw.'nin “yeşil inhibitor” olarak etkisinin ilk kez inceleniyor olmasıdır. Karayosunu ekstraktının inhibitör etkisi, elektrokimyasal impedans spektroskopisi (EIS) tekniği uygulanarak araştırılmıştır. Ekstrakt'ın farklı derişimlerinin bazı zaman parametreleriyle değişimini incelemek amacıyla, EIS ile Nyquist diyagramları oluşturulmuştur. Ayrıca, EIS tekniği ile metalin inhibisyon mekanizması açısından yüzey yükü belirlenmiş ve bunun sonucunda, protonlanmış inhibitör moleküllerinin doğrudan metal yüzeyine adsorplandığı bulunmuştur. Çalışma elektrotlarının yüzey morfoloji incelemeleri alan emisyonlu taramalı elektron mikroskobu (FESEM) ve optik metal mikroskobu teknikleri kullanılarak gerçekleştirilmiştir. Elektrokimyasal deneylerle, yüzey analizi çalışmaları birbirini destekler niteliktedir.

Anahtar kelimeler: Briyofit, Hypnum cupressiforme, Yeşil inhibitor, Asidik korozyon, EIS.

\footnotetext{
* Corresponding author: dozkir@ohu.edu.tr (C) 2020 All rights reserved / Tüm haklarl saklıdır.

To cite this article: Özkır D. Ezer T. 2020. A New Inhibitor Approach to the Corrosion of Mild Steel in Acidic Solution with Long-Term Impedance Tests: A New Application Area for Hypnum cupressiforme (Bryophyta. Anatolian Bryology. 6:2, 119-128.

(c) (1) (2) This work is licensed under a Creative Commons Attribution-Non-Commercial 4.0 International License.
} 


\section{Introduction}

Metallic materials undergo structural degradation called "corrosion" as a result of their interaction both electrochemically and chemically with their environment (Allaoui et al., 2017; Fang et al., 2019). Corrosion is a phenomenon that harms life from industry until it reaches homes (Xu et al., 2013). Since corrosion cannot be virtually eliminated in industrial and many areas, inhibiting and deceleration of corrosion have been their central focuses. In acidic solutions, the application of inhibitors is one of the most common and most influential methods used to protect metals against corrosion. Different organic compounds containing heteroatoms in their structure were synthesized and used as inhibitors on various metal surfaces (Emregül and Hayvali, 2006; Özkır and Çifcibaşı, 2017; Özkır, 2018, 2019). Also, synthetic organic and inorganic inhibitors are also used to prevent corrosion, but their utilization is restricted due to their toxic effects on the environment. For this reason, the trend towards environmentally friendly corrosion inhibitors called "green" is the majority instead of using toxic and harmful chemicals in recent years (Abakedi et al., 2016; Dar, 2011; Oguzie, 2008; Singh et al., 2016).

As a "green" word, it is a branch of technology and science that uses environmentally friendly chemicals and reduces the application of environmentally hazardous materials. Recently, scientists working in the field of corrosion science have drawn attention to the green synthesis of organic inhibitors using techniques such as the ultrasound and microwave method (Aljuhani et al., 2018; Ameta et al., 2015). Besides, different plant extracts (Abdel-Gaber et al., 2006; Alibakhshi et al., 2018) attract researchers for the development of green corrosion inhibitors. Plants are unique assets that turn solar energy into a source of life through photosynthesis. Photosynthesis is a phenomenon that cleans the water, soil and air in the environment (Sheldon, 2016). It is also the raw material of many fruits and vegetables that we use in our daily lives. The use of corrosion inhibitors obtained from plant extracts among all green compounds is important because it is harmless to human health and is of interest for to low environmental toxicity. If we compare the synthetic corrosion inhibitors with the corrosion inhibitors obtained from the plant extract, those obtained from the plant extract are less costly and obtaining is shorter and easier than the inhibitors obtained by synthesizing (Mo et al., 2016; Fang et al., 2019).
To use plant-derived compounds as corrosion inhibitors, it is first necessary to understand the mechanisms to reduce the corrosion rate. Aromatic compounds generally found in their structure have high inhibitory properties and electrochemical activity. The mechanisms of action of plants as corrosion inhibitors are generally as follows: They perform their functions either by adsorbing molecules and ions on the metallic material or by reducing the reaction rate in the cathodic/anodic region or by increasing the electrical resistance of the metal surface (Dar, 2011; Houbairi et al., 2013; Al-Senani, 2016).

Bryophytes, the ancestors of land plants, are spread all over the world from the equator to the poles. The first bryophytes which are probably liverworts most likely appeared in the Ordovician period, about 450 million years ago (Delwiche and Cooper, 2015) and today they have could been still able to survive. Despite its primitive structures, bryophytes have many adaptive features for adaptation to terrestrial life. One of these adaptive features is the biosynthesis of secondary metabolites which are enormously diverse in the bryophytes against environmental stress (biotic or abiotic). The secondary metabolites of the bryophytes such as terpenoids, phenolic compounds, alkaloids are a defense against the competition, microbial attack and, insect or animal predation. Moreover, these metabolites are also important in UV protection, drought tolerance, and freezing survival (Xie and Lou, 2009).

Several studies have reported the successful use of plant extracts containing secondary metabolites as green corrosion inhibitors to inhibit the corrosion of metals in an acidic and alkaline environment (Rani and Basu, 2012; El Ouariachi et al., 2010; Abiola et al., 2007; Okafor et al., 2005; El-Etre, 2003; Ebenso and Ekpe, 1996). In these studies, higher vascular plants were used as plant material. In this context, no published studies on bryophytes which are non-vascular earliest land plants have been encountered as plant material. Therefore, the present study aimed to indicate the usability of bryophytes as green inhibitors against corrosion and revealing their anti-corrosion effects.

The present study is especially important for the first time by testing a corrosion inhibitor of cosmopolitan moss species Hурпит cupressiforme in Turkey. For this purpose, it was aimed to investigate the effect of moss extract as an inhibitor on the corrosion of mild steel in 1.0 $\mathrm{M} \mathrm{HCl}$ solution. It is focused to find out by 
calculating some thermodynamic parameters with which the adsorption isotherm that this green inhibitor is adsorbed on the mild steel surface by electrochemical tests at different concentrations. As a result of all these studies, it has been discussed that the environmentally friendly extract, which is not harmful and toxic, is an application-oriented and highly effective inhibitor.

\section{Materials and Methods}

\subsection{Plant material}

The plant material was collected from AdanaAladağ, Başpınar highplateau, $1014 \mathrm{~m}, 37^{\circ} 33^{\prime} \mathrm{N}$, $35^{\circ} 24^{\prime} \mathrm{E}$, on rock in July 2019 and identified using relevant literature (Smith, 2004; Cortini Pedrotti, 2006).

\subsection{Preparation of extract solutions}

Distilled water and $\mathrm{HCl}$ with analytical grade were used in all test solutions prepared for application in electrochemical experiments. The moss specimens were firstly cleaned from the grounded parts of its roots. Later, $H$. cupressiforme specimens were dried to prepare the stock solution of moss extract in an oven for approximately $2 \mathrm{~h}$ at $80{ }^{\circ} \mathrm{C}$ and the moss specimens were powdered in a pestle. Powdered 7 $\mathrm{g}$ of the moss specimens were weighed and 250 $\mathrm{mL}$ distilled water was added and refluxed for 24 h. The refluxed solution was filtered and the extracted one was light yellow colored (Figure 1).

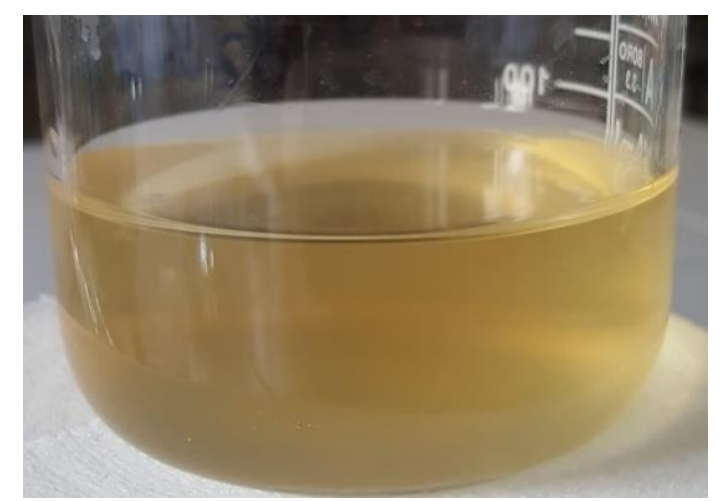

Figure 1. Filtered and evaporated moss extract

The concentration of the stock moss solution studied was $0.202 \%(\mathrm{w} / \mathrm{v})$. Other concentrations were prepared by dilution of the stock solution. The concentration of the stock solution was determined by evaporation of $50 \mathrm{~mL}$ of the moss solution and weighed the residue. Electrochemical measurements were performed in $1.0 \mathrm{M} \mathrm{HCl}$ solution to provide electrolyte medium.

\subsection{Electrodes and electrochemical tests}

Mild steel with the following percentage composition (wt.\%) such as $0.08400 \%$ C, $0.01100 \% \mathrm{P}, \quad 0.06030 \% \mathrm{Cr}, \quad 0.00222 \% \mathrm{Nb}$, $0.07890 \% \mathrm{Ni}, \quad 0.01100 \% \mathrm{~V}, \quad 0.01040 \% \mathrm{Mo}$, $0.21700 \% \mathrm{Cu}, \quad 0.01900 \% \mathrm{~S}, \quad 0.40900 \% \mathrm{Mn}$, $0.01620 \% \mathrm{Sn}, 0.10200 \% \mathrm{Si}, 0.00198 \% \mathrm{Co}$ and $98.977 \% \mathrm{Fe}$ was used as the working electrode. The electrodes were inserted in a cylindrical mold containing polyester and the surface area 0.5024 $\mathrm{cm}^{2}$ of electrodes were exposed to the aggressive medium. The surfaces of the working electrodes were polished with 150 and 600 grids of abrasive paper before each electrochemical test. The electrodes' surfaces were cleaned with acetone and distilled water and allowed to dry at ambient temperature. Three conventional electrode techniques were used for all electrochemical experiments. The first of them is mild steel was used as the working electrode mentioned above. The second one, the counter electrode is a platinum plate with a surface area of $1.0 \mathrm{~cm}^{2}$, and the third one is $\mathrm{Ag} / \mathrm{AgCl}$ as the reference electrode. All potentials granted in this study are given by a reference electrode.

Electrochemical impedance spectroscopy tests were performed using a computer-controlled $\mathrm{CHI}$ 660B model electrochemical analyser. These tests were realized in $1.0 \mathrm{M} \mathrm{HCl}$ solution in without and with different moss extract concentrations. Before all electrochemical measurements, the working electrodes were immersed in the working solution for $1 \mathrm{~h}$ in order to stabilize the system for the open circuit potential $\left(E_{\text {corr }}\right)$. EIS measurements were conducted on the $E_{\text {corr }}$ at a frequency range of $10^{5}$ to $5 \times 10^{-3} \mathrm{~Hz}$ with $5 \mathrm{mV}$ amplitude applied to the system. One, 48 and 120 $\mathrm{h}$ measurements were realized to examine longterm EIS experiments. Surface images were taken $120 \mathrm{~h}$ of duration in aggressive solution (1.0 M $\mathrm{HCl})$ with and without moss extract using metal microscope (digital camera integrated OLYMPUS BX-51 model) and FE-SEM (Zeiss GeminiSEM 500 with computer controlled) techniques. The surface analyses were only performed in a $1.0 \mathrm{M} \mathrm{HCl}$ solution containing without and with $0.05 \%(\mathrm{w} / \mathrm{v})$ moss extract for each surface measurement. The potential of zero charge $\left(E_{p z c}\right)$ of mild steel was found by using EIS method. The values of the polarization resistance $\left(R_{p}\right)$ at open circuit potential were enrolled at \pm $0.200 \mathrm{~V}(\mathrm{Ag} / \mathrm{AgCl})$ ranges and the $R_{p}$ values recorded against their potential values were plotted as a graph. The all electrochemical experiments were conducted at $298 \mathrm{~K}$. 


\section{Results and Discussion}

\subsection{EIS test results}

EIS is one of the most common and practical techniques used to investigate the protective effect of inhibitor molecules on metal (Sürme and Gürten, 2009; Sürme et al., 2011). The most important reason for choosing this method is that it does not disrupt the metal / solution interface in time-based tests. Inhibitor concentrations studied in $1.0 \mathrm{M} \mathrm{HCl}$ solution are $0.001 \%, 0.005 \%$, $0.01 \%, 0.025 \%$ and $0.05 \%(\mathrm{w} / \mathrm{v})$, respectively. The experimental data of the Nyquist diagrams obtained from the electrochemical analyser were enrolled as "txt" files and the equivalent circuit of the system was formed from these data by using Zview2 software. Proposed equivalent electrical circuits (Figure 2) and Nyquist diagrams formed of the mild steel electrodes in hydrochloric acid solution and all concentrations of the moss extract have been indicated for $1 \mathrm{~h}, 48 \mathrm{~h}$ and $120 \mathrm{~h}$ exposure times in Figure 3. Figure 2 shows two types of equivalent circuit models. The first is the equivalent circuit used for the $1.0 \mathrm{M} \mathrm{HCl}$ solution in Figure 2a. The other is the circuit model valid for all inhibitor solutions (Figure 2b).

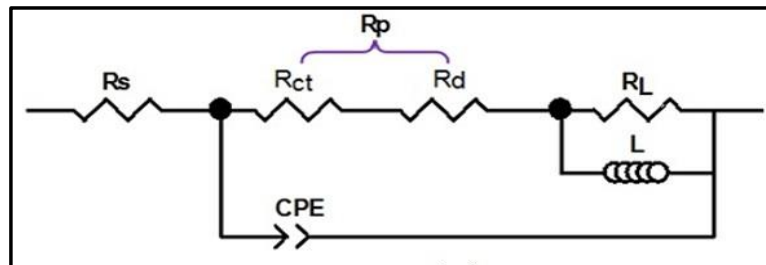

(a)

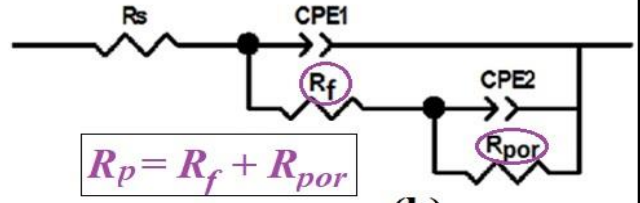

(b)

Figure 2. Proposed equivalent circuits for blank (a) and inhibited (b) solutions

The main difference between the two is the presence of film resistance $\left(R_{f}\right)$ caused by adsorption in inhibited solutions. On the other hand, only for the blank solution are inductive resistance $\left(R_{L}\right)$ and inductance $(L)$. All these equivalent circuits describe the corrosion process, and especially the adsorption process in inhibited solutions. The polarization resistance $\left(R_{p}\right)$ in the equivalent circuit valid for the $1.0 \mathrm{M} \mathrm{HCl}$ solution is responsible for the charge transfer resistance $\left(R_{c t}\right)$ together with the diffuse layer resistance $\left(R_{d}\right)$. However, during the adsorption process of the moss extract to the metal surface, the polarization resistance includes the sum of the film resistance $\left(R_{f}\right)$ and the pore resistance $\left(R_{p o r}\right)$. When pore resistance is referred to here, all types should come to mind from the resistance of the accumulated species $\left(R_{a}\right)$ originating from corrosion products on the metal surface to the charge transfer $\left(R_{c t}\right)$ and diffuse layer resistance $\left(R_{d}\right)$. While the inhibitor adsorbs to a mild steel surface, the contribution of these species is inevitable.

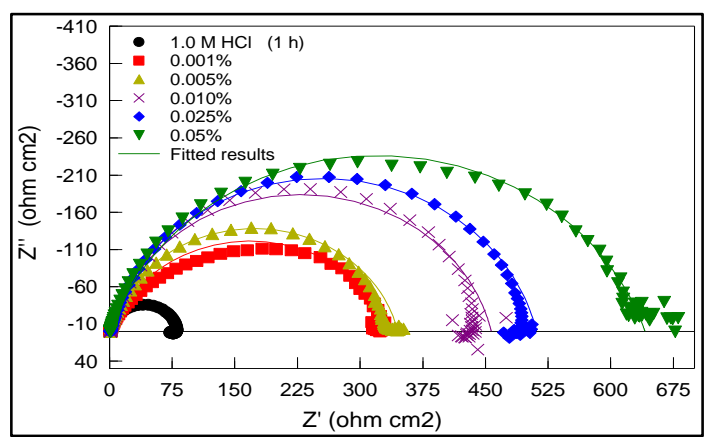

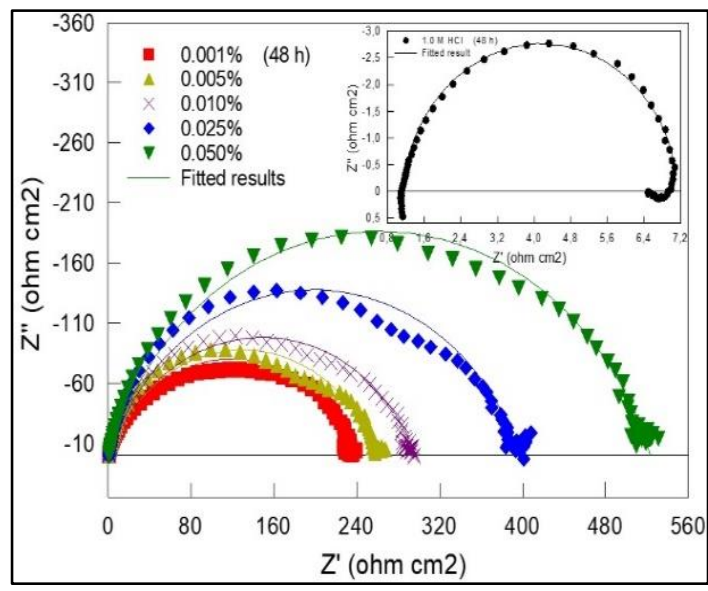

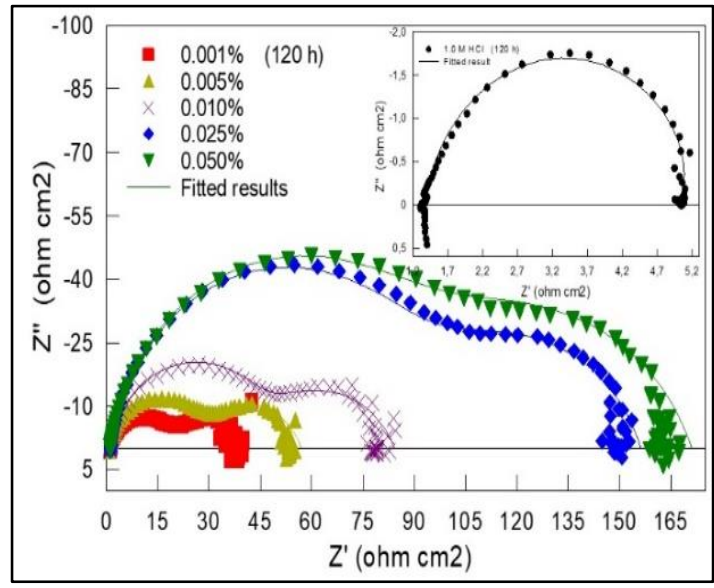

Figure 3. Nyquist plots for mild steel in $1.0 \mathrm{M}$ $\mathrm{HCl}$ in the absence and presence of different moss extract concentrations after 1,48 and $120 \mathrm{~h}$ immersion times 
It is clear that from Figure 3 by adding moss extract to $1.0 \mathrm{M} \mathrm{HCl}$ solution leads to increase resistance owing to the adsorption of bryophyte molecules to the mild steel surface (Özkır et al., 2012). It is indicated that the charge transfer process occurring at the metal/solution interface is delayed with the contribution of the moss and that it is caused by the protective feature of this inhibitor. The impedance parameters related to the adsorption process are also presented in Table 1.

Table 1. The related impedance parameters obtained from fitting results for mild steel $1.0 \mathrm{M} \mathrm{HCl}$ solution with and without containing the moss extract at different exposure time.

\begin{tabular}{|c|c|c|c|c|c|c|c|}
\hline \multirow[t]{2}{*}{ Time } & \multirow{2}{*}{$\begin{array}{c}R_{s} \\
(\Omega \\
\left.\mathbf{c m}^{2}\right) \\
\end{array}$} & \multirow{2}{*}{$\begin{array}{c}R_{p} \\
\left(\Omega \mathrm{cm}^{2}\right)\end{array}$} & \multicolumn{2}{|c|}{ CPE } & \multirow{2}{*}{$\begin{array}{c}R_{L} \\
\left(\Omega \mathrm{cm}^{2}\right)\end{array}$} & \multirow{2}{*}{$\begin{array}{c}L \\
(\mathbf{H})\end{array}$} & \multirow{2}{*}{$\begin{array}{c}\eta \\
(\%)\end{array}$} \\
\hline & & & $\left(\mu \mathrm{F} \mathrm{cm}^{-2}\right)$ & $n$ & & & \\
\hline $1 \mathrm{~h}$ & & & & & & & \\
\hline Blank & 1.2 & 72 & 110 & 0.94 & 8 & 4 & - \\
\hline 0.001 & 1.2 & 334 & 101 & 0.80 & - & - & 78.4 \\
\hline 0.005 & 1.2 & 344 & 91 & 0.86 & - & - & 79.1 \\
\hline 0.010 & 1.0 & 456 & 80 & 0.86 & - & - & 84.2 \\
\hline 0.025 & 1.2 & 510 & 69 & 0.86 & - & - & 85.9 \\
\hline 0.050 & 1.0 & 640 & 55 & 0.81 & - & - & 88.8 \\
\hline$\underline{48 \mathrm{~h}}$ & & & & & & & \\
\hline $\overrightarrow{\text { Blank }}$ & 1.1 & 5 & 10123 & 0.94 & 0.7 & 1 & - \\
\hline 0.001 & 0.8 & 240 & 1037 & 0.74 & - & - & 97.9 \\
\hline 0.005 & 0.9 & 258 & 523 & 0.76 & - & - & 98.1 \\
\hline 0.010 & 1.1 & 296 & 301 & 0.75 & - & - & 98.3 \\
\hline 0.025 & 1.1 & 396 & 107 & 0.77 & - & - & 98.7 \\
\hline 0.050 & 1.1 & 522 & 67 & 0.79 & - & - & 99.0 \\
\hline $120 \mathrm{~h}$ & & & & & & & \\
\hline$\overline{\text { Blank }}$ & 1.4 & 4 & 36520 & 0.89 & 0.4 & 0.3 & - \\
\hline 0.001 & 1.2 & 40 & 5681 & 0.74 & - & - & 90.0 \\
\hline 0.005 & 1.0 & 56 & 3395 & 0.74 & - & - & 92.9 \\
\hline 0.010 & 1.2 & 83 & 1713 & 0.72 & - & - & 95.2 \\
\hline 0.025 & 1.2 & 155 & 514 & 0.77 & - & - & 97.4 \\
\hline 0.050 & 1.1 & 170 & 211 & 0.75 & - & - & 97.7 \\
\hline
\end{tabular}

The protective effect of this moss extract is determined by calculating the percent inhibition efficiency $(\eta \%)$ values for each concentration of the inhibitor at each immersion time. The $\eta \%$ values were calculated with the following equation (Özkır, 2019b):

$\eta(\%)=\left(\frac{R_{p}^{\prime}-R_{p}}{R_{p}^{\prime}}\right) \times 100$

where $\eta \%$ is the percent inhibition efficiency value, $R_{p}^{\prime}$ and $R_{p}$ are in inhibited and uninhibited polarization resistance values, respectively. Depending on immersion times in acidic solutions with and without inhibitor, deviations from the semicircles are observed in the EIS curves. The frequency scattering becomes more evident as the immersion times increase (especially at the end of $120 \mathrm{~h}$ ). Frequency dispersion is also caused by the increment in surface roughness due to prolonged exposure to an acidic solution. In Figure 3, as the concentration rises at each immersion time, $R_{p}$ values enhanced accordingly. The inhibitor protects the mild steel surface at the highest concentration $(0.05 \%)$ with an $89 \%$ effect after a 1-hour immersion time. This is a very good and high result for green inhibitors. As a result, Nyquist diagrams in the moss extract solutions progress in depressed cycles at low and high frequencies. The high frequency loop is responsible for $R_{c t}$ and $R_{d}$, the low one is control of $R_{f}$ and $R_{a}$ (Figure 2). According to EIS diagrams of Figure 3, the resistance values of both hydrochloric acid solution and solutions containing the moss extract decrease as the immersion times increase. In other words, the capacitive loop diameters of Nyquist curves are getting smaller.

It can be seemed clearly from both Figure 3 and Table 1 that the surfaces of mild steels immersed for $48 \mathrm{~h}$ in acidic solutions containing moss extract, have reached a more stable state than the first hour measurements. This means that the inhibitor molecules are adsorbed tightly on the mild steel surface and have a protective effect. It can also be easily understood from the fact that the inhibition efficiency values in Table 1 are above 
$98 \%$ at the end of $48 \mathrm{~h}$. Also, at the end of this period, it can be said that the best inhibition of the mild steel surface is achieved at an optimum concentration as $99.0 \%$. Even at the end of the 120-hour exposure period, the protection effect is still above $90 \%$. The durability of the inhibitor is quite good even after this time. This high inhibition effect results from secondary metabolites known to contain molecules such as phenolic compounds, nitrogenous compounds and terpenes, the main source of which is bryophyte. It can be said that this high effect is caused primarily by the aromatic ring and the $\pi$-electrons in this ring, which are particularly present in phenolic and nitrogenous compounds. There is also an orientation towards the $\mathrm{Fe}$ surface from heteroatoms such as oxygen and nitrogen in phenolic compounds and nitrogenous compounds, and unshared electron pairs in these heteroatoms. In this case, it can be interpreted that it closes the surface like a cover and performs corrosion inhibition. As a result, considering all the immersion times of the inhibitor, extremely successful results were achieved with EIS completely.

CPE is the Constant Phase Element value. CPE values progressively attenuated as concentration increased during all immersion times. This diminish in CPE values is due to the reduction in local dielectric constant or increase of double layer thickness (Obot and Obi-Egbedi, 2011). " $n$ " value is the roughness coefficient of the metal surface. As seen in Table 1 in particular, as the inhibitor was added to the acidic solution, the " $n$ " values were smaller than the uninhibited solution. As the inhibitor molecules are added to the hydrochloride acid solution, the " $n$ " values will gradually get smaller, since the adsorption of these molecules on the mild steel surface will increase (Charitha and Rao, 2018).

In general, adsorption of an inhibitor molecule of organic origin on a metal surface can be explained as follows in the corrosion process; when these molecules begin to move towards the metal in the acidic solution, they gradually undergo a replacement process with other ions and water molecules previously adsorbed in the medium. In this process, the more adsorption and the more inhibition efficiency will be.

\subsection{The surface charge of mild steel}

The adsorption of organic molecules to the metal surface primarily depends on the chemical structure of that molecule. It also depends on parameters such as the type and charge of the metal. The charge of the metal surface can be determined by comparing the open circuit potential $\left(E_{c o r r}\right)$ of the metal with the zero-charge potential $\left(E_{p z c}\right)$ (Prathibha et al., 2017). To determine the surface charge of the mild steel electrode, EIS measurements of different potentials were made in $1.0 \mathrm{M} \mathrm{HCl}$ solution containing $0.05 \%(\mathrm{w} / \mathrm{v})$ moss extract and the $R_{p}$ values measured were plotted against the potential in Figure 4. The measured potential range is \pm $0.200 \mathrm{~V}(\mathrm{Ag} / \mathrm{AgCl})$.

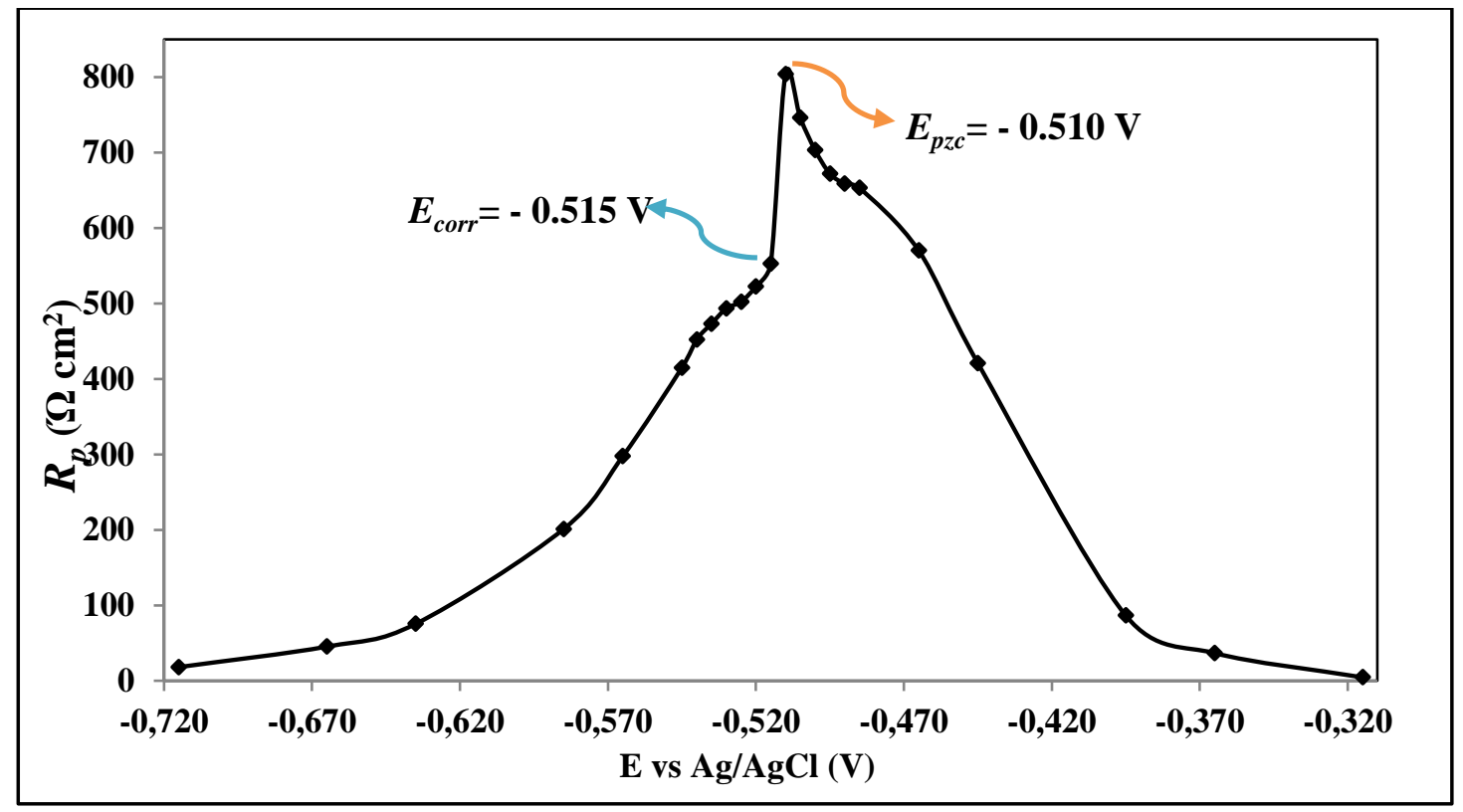

Figure 4. E- $R_{p}$ graph in acidic solution containing $0.05 \%(\mathrm{w} / \mathrm{v})$ moss extract of mild steel electrode at 298 
The surface charge of the metal can be interpreted by comparing the positions of $E_{c o r r}$ and $E_{p z c}$ against each other in Fig. 4. The maximum point in the curve obtained indicates $E_{p z c}$. Referring to Figure 4 , the $E_{\text {corr }}$ value $(-0.515 \mathrm{~V})$ of the mild steel electrode under measuring conditions is more negative than the $E_{p z c}$ value $(-0.510 \mathrm{~V})$. This result shows that the surface of the mild steel electrode is negative under these conditions. According to this result, it can be interpreted that the protonated inhibitor molecules are adsorbed directly to the metal surface or adsorption of cations to the metal surface (Fitöz et al., 2018). Thus, the protective layer formed on the metal surface contributes to the inhibition mechanism
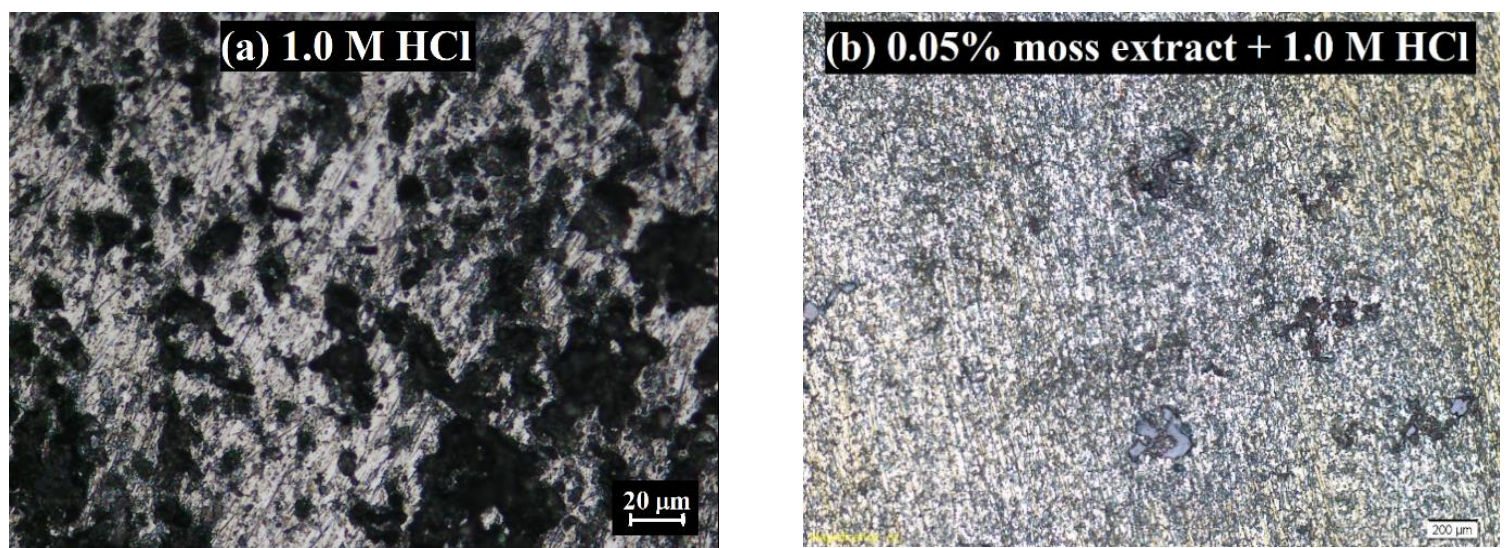

Figure 5. Surface images of the mild steels by optical microscopy after $120 \mathrm{~h}$ at $298 \mathrm{~K}$

When Figures 5(a) and 6(a) are examined, it is observed that the mild steel electrodes, which are kept in an acidic solution for $120 \mathrm{~h}$, are highly by inhibiting the direct interaction of the metal with the chloride solution (Sin et al., 2017; Wang et al., 2018).

\subsection{The surface morphologies of mild steel electrodes}

FESEM and optical microscope surface analyzes were carried out in $1.0 \mathrm{M} \mathrm{HCl}$ with and without moss extract at an optimum concentration at 298 $\mathrm{K}$ and an immersion time of $120 \mathrm{~h}$, providing a detailed understanding of corrosion morphology. Optical microscope (Özkır and Kayakırılmaz, 2020) and FESEM at 200 times magnification (Saraswat et al., 2020) images were evaluated in Figure 5 and Figure 6, respectively.

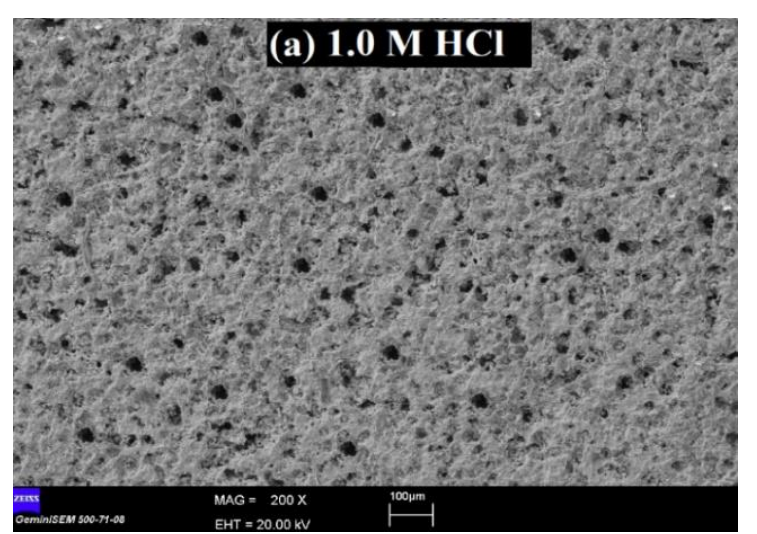

affected by corrosion and deep pits are formed on the surface of the electrode.

Figure 6. Surface images of the mild steels by FESEM after $120 \mathrm{~h}$ at $298 \mathrm{~K}$

When the images in the inhibited solutions in Figure 5(b) and 6(b) are examined, it is seen that it is extremely smooth and more uniform compared to the images in the uninhibited ones. It is clearly observed that the pits are reduced in number and the deep cavities are filled to a considerable extent. It can be concluded that the surface images are another distinguishing indicator that the inhibitor studied is very well protected in the acidic solution of the mild steel electrode.

\section{Conclusions}


This study is quite important for a moss species Hypnum cupressiforme the first application of green inhibitor in Turkey. In the long term, EIS moss extract tests provided a good inhibition by adsorbing the mild steel surface very well with decreasing CPE values in response to increasing $R_{p}$ values. It even showed $98 \%$ inhibition at the highest concentration after $120 \mathrm{~h}$ of immersion. It is concluded that protonated inhibitor molecules are adsorbed directly to mild steel because the surface charge of the metal is negative. Finally, the optical microscope and FESEM images are highly compatible with electrochemical measurements. Surface morphologies clearly showed that the pits in the acidic solution are closed as the inhibitor is added to the medium during the corrosion process.

The anti-corrosion effect of organic substances such as tannins, alkaloids, amino acids and organic dyes of plant origin is important for industry and the environment, as they are biodegradable and free of toxic compounds. Although several studies have been conducted on green corrosion inhibitor using the plant extracts, there is need for more study on this subject. In particular, further studies should be conducted on the use of bryophytes, which form an extremely rich source of bioactive molecules such as terpenoids and aromatic compounds, as a new green inhibitor to protect metals against corrosion.

\section{References}

Abakedi O.U. Moses I.E. Asuquo J.E. 2016. Comparative study on the corrosion inhibition of mild steel by Maesobatrya barteri leaf and root extracts in acidic medium. J. Sci. Eng. Res. 3: 138-144.

Abdel-Gaber A.M. Abd-El-Nabey B.A. Sidahmed I.M. El-Zayady A.M. Saadawy M. 2006. Inhibitive action of some plant extracts on the corrosion of steel in acidic media. Corrosion Science. 48: 2765-2779.

Abiola O.K. Oforka N.C. Ebenso E.E. Nwinuka N.M. 2007. Eco-friendly corrosion inhibitors: The inhibitive action of Delonix regia extract for the corrosion of aluminium in acidic media. AntiCorrosion Methods and Materials. 54: 4, 219-224.

Alibakhshi E. Ramezanzadeh M. Bahlakeh G. Ramezanzadeh B. Mahdavian M. Motamedi M. 2018. Glycyrrhiza glabra leaves extract as a green corrosion inhibitor for mild steel in $1 \mathrm{M}$ hydrochloric acid solution: experimental, molecular dynamics, Monte Carlo and quantum mechanics study. J. Mol. Liq. 255: 185198.

Aljuhani A. El-Sayed W.S. Sahu P.K. Rezki N. Aouad M.R. Salghi R. Messali M. 2018. Microwave-assisted synthesis of novel imidazolium, pyridinium and pyridazinium based ionic liquids and/or salts and prediction of physico-chemical properties for their toxicity and antibacterial activity. J. Mol. Liq. 249: 747-753.

Allaoui M. Rahim O. Sekhri L. 2017. Electrochemical study on corrosion inhibition of iron in acidic medium by Moringa oleifera extract. Orient. J. Chem. 33: 2, 637-646.

Al-Senani G.M. 2016. Corrosion Inhibition of Carbon Steel in acidic chloride medium by Cucumis sativus (cucumber) Peel Extract. Int. J. Electrochem. Sci. 11: 291-302.

Ameta G. Pathak A.K. Ameta C. Ameta R. Punjabi P.B. 2015. Sonochemical synthesis and characterization of imidazolium based ionic liquids: a green pathway. J. Mol. Liq. 211: 934-937.

Charitha B.P. Rao P. 2018. Pullulan as a potent green inhibitor for corrosion mitigation of aluminum composite: Electrochemical and surface studies. Int. J. Biol. Macromol. 112: 461-472.

Cortini Pedrotti C. 2006. Flora dei muschi d'Italia, Bryopsida (II parte). Roma: Antonia Delfino Editore. ISBN: 88-7287-370-3, Antonio Delfino Editore MedicinaScienze. pp. 817-1235.

Dar M.A. 2011. A review: plant extracts and oils as corrosion inhibitors in aggressive Media. Ind. Lubr. Tribol. 63: 4, 227-233.

Delwiche C.F. Cooper E.D. 2015. The Evolutionary Origin of a Terrestrial Flora. Current Biology. 25: 899-910.

Ebenso E.E. Ekpe U.J. 1996. Kinetic study of corrosion and corrosion inhibition of mild steel in $\mathrm{H} 2 \mathrm{SO} 4$ using Parica papaya leaves extract. West African Journal of Biological and Applied Chemistry. 41: 2127.

El-Etre A.Y. 2003. Inhibition of aluminum corrosion using Opuntia extract. Corrosion Science. 45: 11, 2485-2495.

El Ouariachi E. Paolini J. Bouklah M. Elidrissi A. Bouyanzer A. Hammouti B. Desjobert J.M. Costa J. 2010. Adsorption properties of Rosmarinus officinalis oil as green corrosion inhibitors on C38 steel in $0.5 \mathrm{M}$ $\mathrm{H}_{2} \mathrm{SO}_{4}$. Acta Metallurgica Sinica. 23: 1, 13-20. 
Emregül K.C. Hayvali M. 2006. Studies on the effect of a newly synthesized Schiff base compound from phenazone and vanillin on the corrosion of steel in $2 \mathrm{M} \mathrm{HCl}$. Corrosion Science. 48: 4, 797-812.

Fang Y. Suganthan B. Ramasamy R.P. 2019. Electrochemical characterization of aromatic corrosion inhibitors from plant extracts. Journal of Electroanalytical Chemistry. 840: 74-83.

Fitoz A. Nazır H. Özgür nee Yakut M. Emregül E. Emregül K.C. 2018. An experimental and theoretical approach towards understanding the inhibitive behavior of a nitrile substituted coumarin compound as an effective acidic media inhibitor. Corros. Sci. 133: 451-464.

Houbairi S. Essahli M. Lamiri A. 2013. Inhibition of Copper Corrosion in 2 $\mathrm{M} \mathrm{HNO}_{3}$ by the Essential Oil of Thyme Morocco. Port. Electrochim. Acta. 31: 4, 221-233.

Mo S. Luo H.-Q. Li N.-B. 2016. Plant extracts as "green" corrosion inhibitors for steel in sulphuric acid. Chemical Papers. 70: 9, 1131-1143.

Obot I.B. Obi-Egbedi N.O. 2011. Anti-corrosive properties of xanthone on mild steel corrosion in sulphuric acid: Experimental and theoretical investigations, Curr. Appl. Phys. 11: 382-392.

Oguzie E.E. 2008. Evaluation of the inhibitive effect of some plant extracts on the acid corrosion of mild steel. Corrosion Science. 50: 11, 2993-2998.

Okafor P.C. Ekpe U.J. Ebenso E.E. Umoren E.M. Leizou K.E. 2005. Inhibition of mild steel corrosion in acidic medium by Allium sativum extracts. Bulletin of Electrochemistry. 21: 8, 347-352.

Özkır D. Kayakırılmaz K. Bayol E. Gürten A.A. Kandemirli F. 2012. The inhibition effect of Azure A on mild steel in $1 \mathrm{M} \mathrm{HCl}$. A complete study: Adsorption, temperature, duration and quantum chemical aspects. Corrosion Science. 56: 143-152.

Özkır D. Çifcibaşı Ö. 2017. The Investigation of the Adsorption of a Schiff Base Derivated from 2,5-Dichloroaniline as an Inhibitor on Mild Steel Corrosion in Acidic Medium by Electrochemical Methods. Engineering Sciences. 12: 2, 97-107.

Özkır D. 2018. A new example of mild steel corrosion inhibitors synthesized from Chloroaniline: 2-[(2,5dichlorophenylimino)methyl]phenol. OHU J. Eng. Sci. 7: 2, 993-1003.
Özkır D. 2019a. A Newly Synthesized Schiff Base Derived from Condensation Reaction of 2,5-dichloroaniline and benzaldehyde: Its Applicability through Molecular Interaction on Mild Steel as an Acidic Corrosion Inhibitor by Using Electrochemical Techniques. J. Electrochem. Sci. Technol. 10: 1, 37-54.

Özkır D. 2019b. The Electrochemical Variation of a Kind of Protein Staining and Food Dye as a New Corrosion Inhibitor on Mild Steel in Acidic Medium. International Journal of Electrochemistry. 1-11. Article ID 5743952. https://doi.org/10.1155/2019/5743952.

Özkır D. Kayakırılmaz K. 2020. The Inhibitor Effect of (E)-5-[(4(benzyl(methyl)amino)phenyl)diazenyl]1,4-dimethyl-1H-1,2,4-triazol-4-ium zinc(II) Chloride, an Industrial Cationic Azo Dye, onto Reducing Acidic Corrosion Rate of Mild Steel. J. Electrochem. Sci. Technol. (Epub ahead of print). https://doi.org/10.33961/jecst.2019.00703

Prathibha B.S. Nagaswarupa H.P. Kotteeswaran P. BheemaRaju V. 2017. Inhibiting effect of Quaternary ammonium compound on the corrosion of mild steel in $1 \mathrm{M}$ Hydrochloric acid solution, its adsorption and kinetic characteristics. Mater. TodayProc. 4: 11, 12245-12254.

Rani B.E.A. Basu B.B.J. 2012. Green Inhibitors for Corrosion Protection of Metals and Alloys: An Overview. International Journal of Corrosion. 15 pp.

Saraswat V. Yadav M. Obot I.B. 2020. Investigations on eco-friendly corrosion inhibitors for mild steel in acid environment: Electrochemical, DFT and Monte Carlo Simulation approach. Colloids and Surfaces A. 599, 124881124893.

Sheldon R.A. 2016. Green chemistry and resource efficiency: towards a green economy. Green Chem. 18: 3180-3183.

Sin H.L.Y. Rahim A.A. Gan C.Y. Saad B. Salleh M.I. Umeda M. 2017. Aquilaria subintergra leaves extracts as sustainable mild steel corrosion inhibitors in $\mathrm{HCl}$. Measurement. 109: 334-345.

Singh A. Ahamad I. Quraishi M.A. 2016. Piper longum extract as green corrosion inhibitor for aluminium in $\mathrm{NaOH}$ solution. Arab. J. Chem. 9: 2, S1584-S1589.

Smith A.J.E. 2004. The moss flora of Britain and Ireland, Cambridge Univ. Press. Cambridge. 
Sürme Y. Gürten A.A. 2009. Role of polyethylene glycol tert-octylphenyl ether on corrosion behaviour of mild steel in acidic solution. Corros. Eng. Sci. Techn. 44: 4, 304-311.

Sürme Y. Gürten A.A. Bayol E. 2011. Corrosion behavior of mild steel in the presence of scale inhibitor in sulfuric acid solution. Prot. Met. Phys. Chem+. 47: 1, 117-120.

Wang Y. Zuo Y. Tang Y. 2018. Inhibition effect and mechanism of sodium oleate on passivation and pitting corrosion of steel in simulated concrete pore solution, Constr. Build. Mater. 167: 197-204.

Xie C.F. Lou H.X. 2009. Secondary Metabolites in Bryophytes: An Ecological Aspect. Chemistry \& Biodiversity. 6: 303-312.

Xu B. Liu Y. Yin X. Yang W. Chen Y. 2013. Experimental and theoretical study of corrosion inhibition of 3pyridinecarbozalde thiosemicarbazone for mild steel in hydrochloric acid. Corrosion Science. 74: 206-213. 